\title{
Importance of DNA Sequencing for Abnormal Hemoglobins Detected by HPLC Screening
}

\author{
HPLC ile Tanımlanan Anormal Hemoglobinler için DNA Dizilemenin Önemi
}

\author{
(D) Duran Canatan1,2, (D) Abdullah Çim¹, (D) Serpil Delibaş2, (D) Emel Altunsoy'1, (D) Serdar Ceylaner 3 \\ ${ }^{1}$ Antalya Genetic Diseases Diagnosis Center, Antalya, Turkey \\ 2Mediterranean Blood Diseases Foundation - Hemoglobinopathy Diagnosis Center, Antalya, Turkey \\ 3/ntergen Genetic Diseases Diagnosis Center, Ankara, Turkey
}

To the Editor,

Hemoglobinopathies are the most common health problem in Turkey. A hemoglobinopathy prevention program has been implemented by the Ministry of Health in Turkey in 33 provinces since 2003 and it spread to all 81 provinces in 2018 [1]. Our hemoglobinopathy diagnostic center has been licensed for 16 years [2]. The aim of this study was to compare the molecular genetic analysis and high-performance liquid chromatography (HPLC) results for abnormal hemoglobins. Blood samples were directed from local primary health care centers, hospitals, and laboratories in the context of premarital screening processes. Complete blood count (CBC) and HPLC methods were applied for all blood samples. Abnormal hemoglobins or abnormal bands were detected in 219 (0.67\%) of 32,513 blood samples between 2013 and 2019. DNA sequencing was performed for 190 of 219 samples. Of those 190 samples, 38 were abnormal bands, 76 were $\mathrm{HbS}, 49$ were $\mathrm{HbD}, 6$ were $\mathrm{HbC}$, and 21 were $\mathrm{HbE}$. While ten different mutations were detected in 24 cases (63.2\%), they were not found for 14 (36.8\%) of 38 abnormal bands (Table 1). In addition, molecular analysis confirmed 69 cases of $\mathrm{HbS}$ (90.8\%) from among $76 \mathrm{HbS}, 42 \mathrm{HbD}$ Punjab (85.7\%) in $49 \mathrm{HbD}$, $4 \mathrm{HbC}(66.7 \%)$ in $6 \mathrm{HbC}$, and $4 \mathrm{HbE}(19 \%)$ in $21 \mathrm{HbE}$ samples detected by HPLC.

Al-Madhani et al. [3] screened 3740 newborns and compared the results of $\mathrm{CBC}$ and $\mathrm{HPLC}$ with the molecular genetic analysis results for 290 newborns. They confirmed 26 cases of homozygous sickle cell anemia and 5 of homozygous $\beta$-thalassemia major by DNA sequencing among 31 newborns [3]. Warghade et al. [4] screened 65,779 cases for hemoglobinopathy using cationexchange (CE)-HPLC and abnormal hemoglobin fractions were observed in 12,131 (18.44\%) cases. They confirmed eight rare hemoglobin variants by beta-globin gene analysis for those samples that could not be distinguished by CE-HPLC [4]. Chen et al. screened couples of reproductive age using HPLC and reported $1.14 \%$ hemoglobinopathy in the Chinese city of

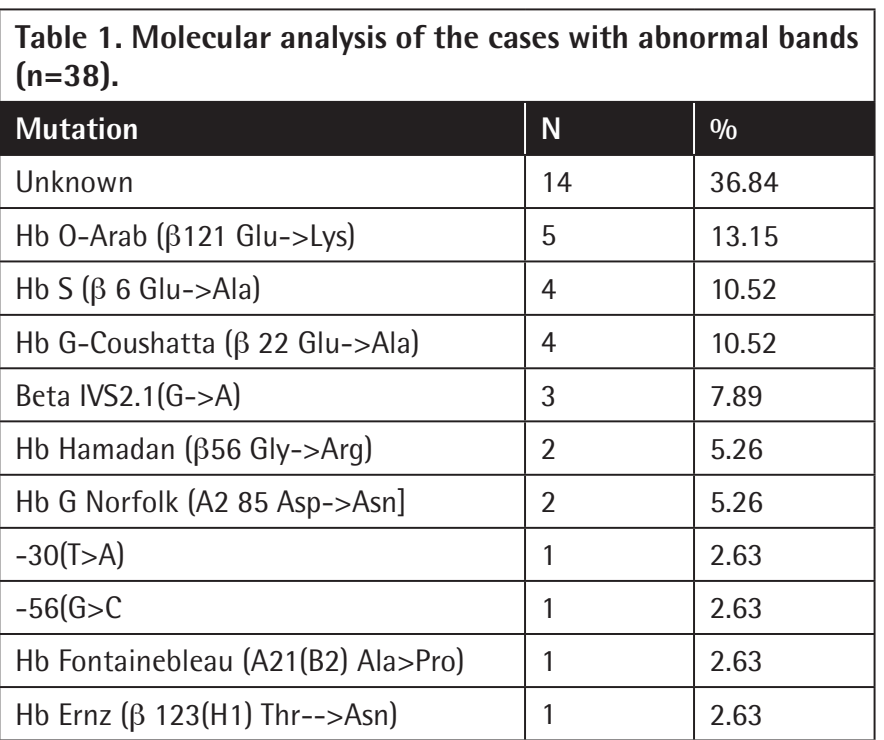

Guangzhou. They reported 8 different abnormal hemoglobins by molecular techniques [5].

In the present study, the concordance of sequencing analysis with the HPLC results was $90.8 \%$ for $\mathrm{HbS}, 85.7 \%$ for $\mathrm{HbD}, 66.7 \%$ for $\mathrm{HbC}$, and 19\% for $\mathrm{HbE}$. Interestingly, 10 different abnormal hemoglobin variants have been detected using DNA sequencing in 24 of $38(63.2 \%)$ samples with abnormal bands. Therefore, the type of abnormal hemoglobin can be determined more precisely using molecular analysis.

In conclusion, whatever screening method is used in hemoglobinopathy diagnosis centers, all reports should include the following expression: "This is a screening test; molecular analysis should be carried out for a definite result". Taking into account the different results obtained in screening and molecular analysis, physicians working in these centers should be offered access to molecular analysis for all abnormal hemoglobins and abnormal bands. 
Keywords: Hemoglobinopathy, HPLC, DNA, Sequencing

Anahtar Sözcükler: Hemoglobinopati, HPLC, DNA, Dizileme

Informed Consent: As a result of the explanations, the patients voluntarily asked for the tests to be conducted.

\section{Authorship Contributions}

Concept: D.C.; Design: D.C.; Data Collection or Processing: S.D., A.Ç., E.A.; Analysis or Interpretation: D.C., A.Ç., S.C.; Literature Search: D.C., A.Ç.; Writing: D.C., A.Ç.

Conflict of Interest: The authors of this paper have no conflicts of interest, including specific financial interests, relationships, and/or affiliations relevant to the subject matter or materials included.

\section{References}

1. Canatan $D$, Kose $M R$, Ustundağ $M$, Haznedaroglu $D$, Ozbaş $S$. Hemoglobinopathy control program in Turkey. Community Genet 2006;9:124-126.

2. Canatan $D$, Delibas S. Report on ten years' experience of premarital hemoglobinopathy screening at a center in Antalya, Southern Turkey. Hemoglobin 2016;40:273-276.

3. Al-Madhani A, Pathare A, Al Zadjali S, Al Rawahi M, Al-Nabhani I, Alkindi S. The use of HPLC as a tool for neonatal cord blood screening of haemoglobinopathy: a validation study. Mediterr J Hematol Infect Dis 2019; 11:e2019005.

4. Warghade S, Britto J, Haryan R, Dalvi T, Bendre R, Chheda P, Matkar S, Salunkhe $Y$, Chanekar M, Shah N. Prevalence of hemoglobin variants and hemoglobinopathies using cation-exchange high-performance liquid chromatography in central reference laboratory of India: a report of 65779 cases. J Lab Physicians 2018;10:73-79.

5. Chen GL, Qu YX, Jiang F, Tang $Y$, Tang F, Zuo LD. Screening abnormal hemoglobin diseases for couples of childbearing age in Guangzhou City by HPLC. Zhongguo Shi Yan Xue Ye Xue Za Zhi 2017;25:1768-1771.

๑Copyright 2020 by Turkish Society of Hematology

Turkish Journal of Hematology, Published by Galenos Publishing House

\title{
Two Rare Pathogenic HBB Variants in a Patient with $\beta$-Thalassemia Intermedia
}

\author{
Bir Beta Talasemi Intermedya Hastasında Iki Nadir Patojenik HBB Varyantı
}

(D) Veysel Sabri Hançer1, (D) Tunç Fışgın², (D) Murat Büyükdoğan³

1istinye University Faculty of Medicine, Department of Medical Biology, Istanbul, Turkey

2Altınbaş University Faculty of Medicine, Department of Pediatrics, istanbul, Turkey

3istinye University Faculty of Medicine, Department of Medical Genetics, Istanbul, Turkey

To the Editor,

The $\beta$-thalassemias are a group of hereditary disorders with autosomal recessive inheritance characterized by the presence of defective synthesis of the $\beta$-globin chain, an integral component of the hemoglobin molecule, resulting in either partial synthesis $\left(\beta^{+}\right)$or complete absence $\left(\beta^{0}\right)$ [1]. The disease reaches a high frequency in the Mediterranean Basin, Africa, the Middle East, the Indian subcontinent, and Southeast Asia [2]. According to the World Health Organization, the frequency of abnormal hemoglobin is $7 \%$ globally [3]. $\beta$-Thalassemia major is characterized by completely inhibited synthesis of beta chains [4], and so it must be treated, generally by transfusion therapy [4]. The $\beta$-thalassemia major phenotype has homozygotes or compound heterozygotes for $\beta^{0}$ or $\beta^{+}$genes. Generally, mutations targeting the coding regions of the gene and conservative regions on the exon-intron boundary lead to $\beta^{0}$-thalassemia, and mutations in regions that do not encode $\beta^{+}$-thalassemia. In contrast to the major type, the presence of one normal gene in heterozygotes usually leads to enough normal $\beta$-globin chain synthesis so that the affected individuals are usually asymptomatic with only hypochromic and microcytic red blood cells. This condition is referred to as $\beta$-thalassemia minor [5]. $\beta$-Thalassemia intermedia clinically differs from the major and minor ones with respect to the necessity of transfusion. The degree of anemia for $\beta$-thalassemia major is more aggravated than that for $\beta$-thalassemia intermedia. The genotype of $\beta$-thalassemia intermedia is mostly 